\title{
TRANSLATING A SUNDANESE NOVELETTE: PROBLEMS AND CHALLENGES
}

\author{
Rika Novia Dewi and Dedy Setiawan ${ }^{1}$ \\ English Department - Politeknik Negeri Bandung, Indonesia
}

\begin{abstract}
Translation initially is transferring an idea from one into another language. The idea translated is in a form of concept or messages which the writer puts in his/her writing. Translating a literary work is more than just trsnfering concept or story flow, arising from the art work, it should also be able to illustrate the message which can be culturally or literally impacted. This article describes an experience of the wrirters when translating a Sundanese novellete which is full of cultural aspect which is specific to a particular ethnic group in Indonesia. It also elaborates the translation process, the method used and discussion translating cultural words.
\end{abstract}

Keywords: Sundanese, culture, translation process, cultural words

\section{Introduction}

Language and culture are two aspects that cannot be separated. People use language to communicate with other people. Usually, the same language is used by people who live in the same culture. However, nowadays many people are involved in other cultures and want to learn about them. Thus, translation is needed to facilitate those people. Furthermore, Durdureanu (2011) emphasized:

If translation did not exist, it would be difficult to communicate ..., by communication meaning not only the transmission of words and phrases but also the sense of a text, because what translators should translate is messages, senses, and texts. (p. 51)

\footnotetext{
${ }^{1}$ Corresponding Author
} 
Basa Sunda (Sundanese language) is one of the ethnic languages in Indonesia. It is spoken mostly by Sundanese people living in most area in West Java. According to Mustakim (2013), basa Sunda has shown 3.9\% in extinction rate. The percentage showed the loss of the language speakers. It was higher than bahasa Banjar (2.5\%), bahasa Madura (2.2\%), and bahasa Bali $(2.1 \%)$. Thus, it is important to preserve basa Sunda so that it can be saved from extinction. Translating from basa Sunda into English can be one of the ways to preserve basa Sunda.

Translation is not a new field of study. People translate from one language into another. However, translation project on literary work from basa Sunda into English is rarely conducted. It can be seen from the fact that in some libraries in Bandung, such as Badan Perpustakaan Dan Arsip Daerah (BAPUSIPDA) Provinsi Jawa Barat, Perpustakaan Deposit Jawa Barat, as well as Perpustakaan Ajip Rosidi that specifically accomodates Sundanese books and literature, the book about translation from basa Sunda to English could not be found. Thus the making of this translation project could enrich the variety of translation from basa Sunda to another foreign language and the rarity of translation from basa Sunda to English can be reduced.

Before deciding to choose the book entitled $\mathrm{Nu}$ Ngageugeuh Legok Kiara, three other books were considered. They consist of compiled short stories entitled Oray Bedul Macok Mang Konod (Romli, 2010) and two novelettes entitled Nyi Sarikingkin (Djajadilaga, 2014) and Si Pucuk Kalumpang (Rosidi, 2012). However, Oray Bedul Macok Mang Konod is considered to be difficult since it contains humour which is not easy to be translated. While Nyi Sarikingkin has very similar story with Cinderella and the result of the translation will be also similar with Cinderella original story. Si Pucuk Kalumpang is not chosen because the story contains violence that is considered unsuitable for children.

We then chose the novelette $\mathrm{Nu}$ Ngageugeuh Legok Kiara as it has good moral message, not only for children but also for adults. It tells about the culture and belief of Sundanese people.

The translation of Sundanese novelette was intended to introduce and to promote Sundanese culture to the reader. In addition, we would like to share the Sundanese cultural value arising from the novelette. 


\section{Literature Review}

According to (Durdureanu, 2011), "Translation and culture are so interrelated that translators can no longer ignore cultural elements in a text" (p. 51). In the result of her research, she suggested that to translate cultural terms is possible. By using some strategies from various translation experts, translating text that contains some cultural elements can be done.

The only Sundanese book which we have found translated into English is entitled The People's Religion (2008). It uses Basa Sunda as the source language and English as target language. In the book, some translation procedures such as notes in the form of footnote as well as recognized translation are applied. Those make the translation result readable with clear meaning. For the novel and other literary works, we have not found them translated yet.

While Indonesian, novels, there are a lot which are already translated into English and found in the market. A novel entitled The Rainbow Troops by Andrea Hirata (2009) (Translated by Angie Kilbane) and Legenda Ajisaka: Asal Mula Aksara Jawa - Legend of Ajisaka : Chronicle of Hanacaraka (Restanto, 2011) are also reviewed. In both of the books, the translation is easy to understand. The name such as Bu Mus, Pak Harfan, and Dewatacengkar as well as cultural words e.g. kopiah, jilbab, and keris are maintained to keep the cultural aspects. Most of the sentences in the second book are short simple sentence, so it will be easier for children to understand. However, some grammatical and spelling errors are found.

\footnotetext{
About the translation

According to Ordudari (2007), Translation typically has been used to transfer written or spoken SL texts to equivalent written or spoken texts. In general, the purpose of tranlation is to produce various kinds of text ... in another language and thus making them available to wider readers. (p. 1)

Likewise, Bassnett (1994) mentioned that conventionally, translation ... involves the rendering of a source language (SL) text into the target language (TL) so as to ensure that (1) the surface meaning of the two will be approximately similar and (2) the structures of the SL will be preserved as closely as possible but not so closely that the TL structures will be seriously distorted. (p.2).
} 
Meanwhile, Nida (1984:83) discovered that "translation consists of reproducing in the receptor language the closest natural equivalent of the source message, first in terms of meaning and secondly in terms of style" (qtd. in Ordudari, 2008, par. 7). Then Newmark stated that translation is expressing in another language "the meaning of a text ... in the way that the author intended the text," (1988:5).

\section{The Translation Process}

To transfer the meaning in translation, a translator needs to follow several steps. Larson $(1984$, p.4) presents the process of translation in a diagram.

\section{Source Language}

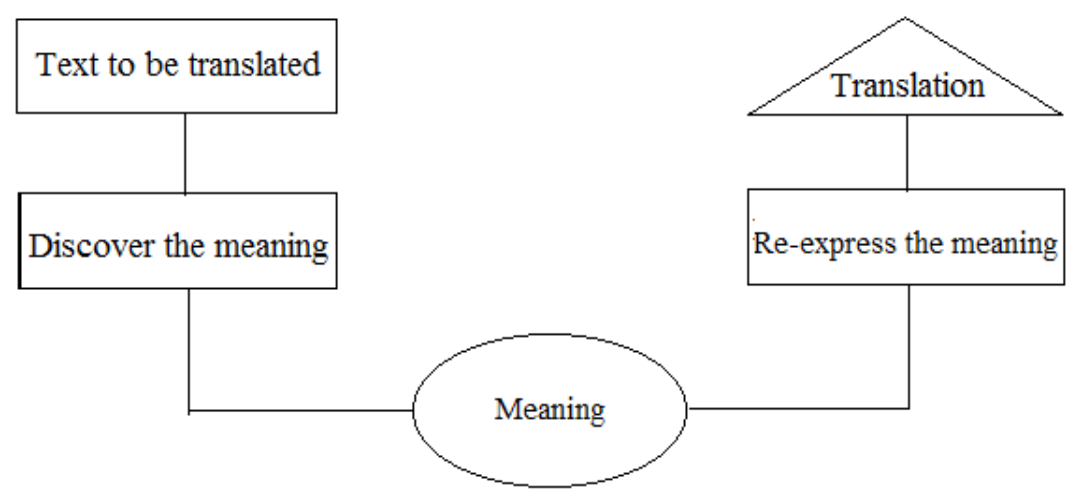

Receptor Language

Figure 1 Translation Process by Larson

What we have done when translating the novelette is similar with what is described above. The process begins from providing the text in source language, in this case is a sundanese novelette. Then the translator should discover the meaning that is going to be transfered into receptor language. Hence, we read and tried to comprehend all bout the novelette; and at the same time we figured out the unusual words such as cultural words, words which are to be translated and strange or unfamiliar words. After the meaning has been discovered and understood very well, the translator reexpresses the meaning in the way that is accepted in receptor language. Finally the result is the text that has been been translated into receptor language. 


\section{Translation methods and translation procedures}

In translating a text, some translation methods and translation procedures can be applied to produce an accurate and natural translation. Newmark stated that the translation methods and translation procedures differ from the object in which they are applied. He mentioned that translation methods are applied in the "whole text" while translation procedures "are used for sentences and the smaller unit of language" (1988:81).

Of the eight translation methods that are proposed by Newmark (1988) such as Word-for-word translation, Literal translation, Faithful translation, Semantic translation, Adaptation, Free translation, Idiomatic translation, and Communicative translation, the most widely used methods are free translation and communicative translation. This is because these two types of translations translate the 'concept' or content rather than 'the language'.

The translation method applied when translating the novelette is communicative translation because according to Newmark (1988), “... only semantic and communicative translation fulfil the two main aims of translation ..." (p. 41). The translation will involve some translation procedures. In doing the translation, several dictionaries such as English English dictionary, Basa Sunda - English dictionary, English - Basa Sunda dictionary, Basa Sunda - Basa Sunda dictionary are used.

In addition, since the source text contains a lot of proper nouns and cultural bound words, below are the list of translation procedures by Newmark (1988) that can be applied to subunit of the text such as words and phrases. 


\section{Table 1: Translation Procedures}

\begin{tabular}{|c|c|}
\hline $\begin{array}{l}\text { Translation } \\
\text { procedures }\end{array}$ & Explanation \\
\hline Transference & $\begin{array}{l}\text { This procedure is used when the translator applies the exact } \\
\text { word from the source language (SL) to the text in target } \\
\text { language (TL). Then Newmark (1988) mentioned that the word } \\
\text { becomes „loan word }{ }^{\text {ee }} \text {. }\end{array}$ \\
\hline Naturalization & $\begin{array}{l}\text { This procedure is the completion of transference procedure. It } \\
\text { makes the words or phrases in SL sounds natural in TL by } \\
\text { adapting them to "normal pronunciation" to the "normal } \\
\text { morphology" (Newmark, } 1988, \text { p. } 82 \text { ). }\end{array}$ \\
\hline Cultural equivalent & $\begin{array}{l}\text { Cultural equivalent employs "approximate translation where an } \\
\text { SL cultural word is translated by a TL cultural word" } \\
\text { (Newmark, 1988, pp. 82-83). }\end{array}$ \\
\hline Functional equivalent & $\begin{array}{l}\text { This procedure needs words that are not related to particular } \\
\text { culture and makes the SL word neutral and general. It is } \\
\text { applied to cultural words. }\end{array}$ \\
\hline Descriptive equivalent & $\begin{array}{l}\text { Sometimes it produces "new specific term" and adds more } \\
\text { words for giving clearer explanation. Newmark (1988) } \\
\text { emphasised that this procedure is "the most accurate way of } \\
\text { translating" because it deculturalizes a cultural word. }\end{array}$ \\
\hline Synonymy & This procedure transfers the SL word with the description of it. \\
\hline Through-translation & $\begin{array}{l}\text { The procedure is employed when the equivalent of the SL } \\
\text { word is unclear. Then the SL word in is translated to TL word } \\
\text { that has near equivalent in a context. }\end{array}$ \\
\hline Modulation & $\begin{array}{l}\text { Through-translation applies literal translation in translating } \\
\text { common collocations, names of organisations, components of } \\
\text { compounds and phrases. }\end{array}$ \\
\hline Shift or Transposition & $\begin{array}{l}\text { This procedure changes the point of view from SL to TL. In } \\
\text { this procedure, "..the double negative is not as forceful as the } \\
\text { positive...". It can also be in the form of: } \\
\text { - abstract for concrete, } \\
\text { - cause for effect, }\end{array}$ \\
\hline
\end{tabular}




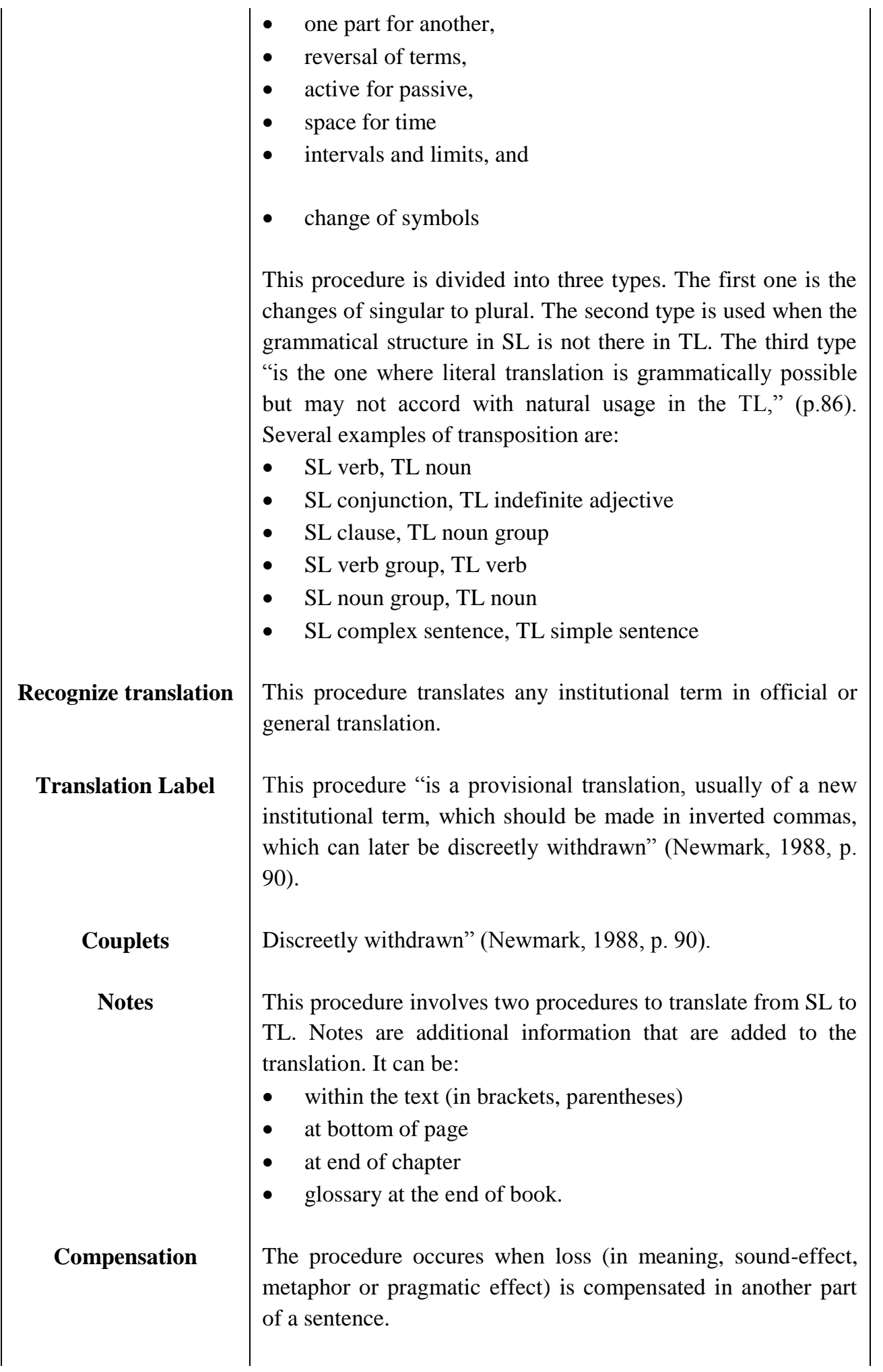




\begin{tabular}{|l|l|}
$\begin{array}{c}\text { Reduction or } \\
\text { Expansion } \\
\text { Equivalence }\end{array}$ & $\begin{array}{l}\text { These procedures delete or add more words in order to } \\
\text { have clearer meaning in TL. } \\
\text { According to Vinay and Dalbernet (1965) (qtd. in Newmark, } \\
1988, \text { p. 90) equivalence is "an unfortunately named term } \\
\text { implying approximate equivalence, accounting for the same } \\
\text { situation in different terms. .. } \\
{[\text { T]hey are simply referring to notices, familiar alternatives, }} \\
\text { phrases and idioms." } \\
\text { Adaptation }\end{array}$ \\
$\begin{array}{l}\text { Vinay and Dalbernet (1965) (qtd. in Newmark, 1988, p. 90) } \\
\text { also proposed a procedure named adaptation. This procedure } \\
\text { changes words/phrases from SL into a common form in TL, } \\
\text { for instance: Dear Sir - Yang Terhormat. }\end{array}$ \\
Explicitation \\
$\begin{array}{l}\text { Delisle (1999) proposed this procedure in order to inform } \\
\text { precise details of source text for clarification. }\end{array}$
\end{tabular}

Adapted from Newmark

In general, the translation method that is preferably used is communicative translation. Then the procedures will be applied in translating the sentences, phrases, or words in the novelette.

\section{Cultural Words}

Cultural words are words or phrases that are related to a specific culture and that do not have any equivalence in other culture. Cultural terms are words or phrases that are related to a specific culture and that do not have any equivalence in other culture. Newmark (1988)) clearly stated,

In theory, names of single persons or objects are 'outside languages, belong ... to the encyclopaedia not the dictionary, have ... no meaning or connotations, are, therefore, both untranslatable and not to be translated. (p.70)

Newmark (1988) also proposed cultural categories as follow:

1. Ecology: e.g. flora, fauna, winds, plains, hills

2. Material culture (artefacts):
a. Food
b. Clothes
c. Houses and towns
d. Transport 
3. Social culture: work and leisure

4. Organisations, customs, activities, procedures, concepts

a. Political and administrative

b. Religious

c. Artistic

5. Gestures and habits

According to Larson (1984), there are three aspects that should be considered. They are accuracy (the translator should transfer the very accurate meaning into the target language), readability (the result of the translation should be understood by the reader), and naturalness (the translation does not sound unnatural in target language). in order to produce a good quality translation, those aspects should be fulfilled.

To translate tricky words or words which are rarely used or hard to be translated, I consult the words with the native speakers of basa Sunda and then I crosscheck to the author of the novelette to confirm the intended meaning.

\section{Result and Discussion}

The result of the project is a translation book entitled The Keeper of Legok Kiara. The word "The Keeper" is used to represent the words "Nu Ngageugeuh" as they have similar meaning. The translated book is available in the main library of Polban and English Department.

\section{Translation Procedures}

Translation procedures were very helpful in doing this translation project. While translating the story, we found some difficulties in translating some words, phrases, and clauses. To overcome those, we looked again into the translation procedures by Newmark. They give alternatives of how to translate a word, phrase, or sentence appropriately.

As the result, the translation procedure mostly used for the difficult words is notes with $26 \%$. This is followed by tranference with $15 \%$. The transference procedure was used for name of the character and name of place. Besides this procedure was applied to a cultural word that has been mentioned before in the translation. The third most used procedure is modulation. After that, transposition is the fourth most used procedure. It is 
followed by equivalent, synonymy, explicitation, reduction, expansion, through-translation, descriptive equialent, functional equivalent, compensation, translation label, an adaptation. Meanwhile, recognised translation, naturalization, and cultural equivalent procedures are not used procedures. Here is the list of the procedures and their percentage presented in a table below:

Table 2 The Percentage of Used Procedures

\begin{tabular}{|c|l|c|c|}
\hline No & \multicolumn{1}{|c|}{ Translation procedures } & Number & \% \\
\hline 1 & Notes & 24 & $\mathbf{2 6 \%}$ \\
\hline 2 & Transference & 14 & $\mathbf{1 5 \%}$ \\
\hline 3 & Modulation & 8 & $\mathbf{1 3 \%}$ \\
\hline 4 & Transposition & 7 & $\mathbf{9 \%}$ \\
\hline 5 & Equivalence & 5 & $\mathbf{5 \%}$ \\
\hline 6 & Synonymy & 4 & $\mathbf{4 \%}$ \\
\hline 7 & Explicitation & 4 & $\mathbf{4 \%}$ \\
\hline 8 & Reduction & 3 & $\mathbf{3 \%}$ \\
\hline 9 & Expansion & 3 & $\mathbf{3 \%}$ \\
\hline 10 & Through-Translation & 2 & $\mathbf{3 \%}$ \\
\hline 11 & Descriptive Equivalent & 1 & $\mathbf{1 \%}$ \\
\hline 12 & Functional Equivalent & 1 & $\mathbf{1 \%}$ \\
\hline 13 & Compensation & 1 & $\mathbf{1 \%}$ \\
\hline 14 & Translation Label & 0 & $\mathbf{0 \%}$ \\
\hline 15 & Adaptation & 0 & $\mathbf{0 \%}$ \\
\hline 16 & Recognised Translation & $\mathbf{0 \%}$ \\
\hline 17 & Naturalization & $\mathbf{1 0 0 \%}$ \\
\hline 18 & Cultural Equivalence & & \\
\hline & & & \\
\hline
\end{tabular}

The first procedure used is notes. Three kinds of notes (within text in brackets, as footnote, and glossary) were used in the translation to give clear meaning to the reader.Here are the examples. 
Table 3 Examples of Notes Procedure

\begin{tabular}{|l|l|}
\hline \multicolumn{1}{|c|}{ Original Text } & \multicolumn{1}{c|}{ Translated Text } \\
\hline Timbel & timbel (rice that is covered by banana leaves) \\
\hline Sééng & $\begin{array}{l}\text { sééng (traditional cooking equipment made of steel, used for } \\
\text { steaming, boiling water, etc.) }\end{array}$ \\
\hline Kongkoak & kongkoak (wild offsprings) \\
\hline Nini Anteh ${ }^{9}$ & $\begin{array}{l}\text { 9 Nini Anteh is a Sundanese myth that told about an old woman who flew and then lived in the } \\
\text { moon with her cat named Candramawat }\end{array}$ \\
\hline
\end{tabular}

The next translation procedure applied is transference. It transfers the exact word of the source text to the target text. Newmark (1988) mentioned it as a loan-word. This procedure is applied when translating a proper noun such as name and place. It is also used for a cultural word that is mentioned for the second time in the translation. The application of this procedure can be seen in the table below.

Table 4 Examples of Transference Procedure

\begin{tabular}{|l|l|}
\hline \multicolumn{1}{|c|}{ Original Text } & \multicolumn{1}{c|}{ Translated Text } \\
\hline $\begin{array}{l}\text { Di dinya urang lembur Cihaur nu rék moro } \\
\text { beurit mani geus ngagimbung }\end{array}$ & $\begin{array}{l}\text { There, people from Cihaur village who } \\
\text { were going to hunt the rats had gathered. }\end{array}$ \\
\hline Emod ngiuhan handapeun tangkal kalapa. & Emod take shade under the coconut tree. \\
\hline Si Sadun ngaharéwos ka Emod. & Si Sadun whispered to Emod. \\
\hline
\end{tabular}

The next is modulation procedure. It is done by changing the point of view of the SL to the TL. Below is the example of the modulation procedure.

Table 5 Examples of Modulation Procedure

\begin{tabular}{|l|l|l|}
\hline \multicolumn{1}{|c|}{ Original Text } & \multicolumn{1}{|c|}{ Translated Text } & Type of Modulation \\
\hline $\begin{array}{l}\text {.. ngan sok dicarék baé } k u \\
\text { indungna. }\end{array}$ & $\begin{array}{l}\text {..his mother always forbade } \\
\text { him to go there. }\end{array}$ & Active - passive \\
\hline $\begin{array}{l}\text { Tong boroning barudak, } \\
\text { dalah kolot ogé langka pisan } \\
\text { anu ngalanto ka Legok } \\
\text { Kiara mah. }\end{array}$ & $\begin{array}{l}\text { Nobody was brave enough } \\
\text { to go there, even the grown- } \\
\text { ups. }\end{array}$ & Change point of view \\
\hline $\begin{array}{l}\text { Dituturkeun ku Ma Emod. } \\
\text { Ma Emod followed his } \\
\text { husband }\end{array}$ & Active-passive \\
\hline
\end{tabular}


After that, transposition procedure is used when the source text when the grammar or word order is not common in TL. Therefore the word order should be changed to make the translation sound natural.

Table 6 Examples of Transposition Procedure

\begin{tabular}{|l|l|}
\hline \multicolumn{1}{|c|}{ Original Text } & \multicolumn{1}{c|}{ Translated Text } \\
\hline $\begin{array}{l}\text { Geus mindeng pisan Emod ngadéngé éta } \\
\text { tempat téh. }\end{array}$ & $\begin{array}{l}\text { Emod had heard about that place way too } \\
\text { often. }\end{array}$ \\
\hline $\begin{array}{l}\text { Sabangsaning sampeu jeung hui oge mani } \\
\text { hese kaalaana. }\end{array}$ & $\begin{array}{l}\text { It was so hard to harvest the cassavas and } \\
\text { potatoes too }\end{array}$ \\
\hline Subuh kénéh Emod geus hudang & Emod woke up really early \\
\hline
\end{tabular}

The next used procedure is equivalence. According to Vinay and Dalbernet (1965), translation of notices, idiom and phrases in the similar situation is included in this procedure. The example of application of this procedure is in the following table.

\section{Table 7 Examples of Equivalence Procedure}

\begin{tabular}{|l|l|}
\hline \multicolumn{1}{|c|}{ Original Text } & \multicolumn{1}{c|}{ Translated Text } \\
\hline $\begin{array}{l}\text { Wah, moal teu sarua jeung beuteung } \\
\text { munding }\end{array}$ & I guess it is as big as an elephant." \\
\hline Ceuk beja mah, & A little bird told me \\
\hline
\end{tabular}

Then the through translation is used when the TL has the same equivalence with the word in SL. Here are the examples.

Table 8 Examples of Through Translation Procedure

\begin{tabular}{|c|c|}
\hline Original Text & Translated Text \\
\hline Sakalor & Epilepsy \\
\hline Sawah tadah hujan & Rainfed fields \\
\hline
\end{tabular}

The next procedure is descriptive equivalent. It changes a word or phrase by giving the description of it. Here is the example of the descriptive equivalent.

Table 9 Examples of Descriptive Equivalent Procedure

\begin{tabular}{|l|l|}
\hline \multicolumn{1}{|c|}{ Original Text } & \multicolumn{1}{c|}{ Translated Text } \\
\hline barudak saur manuk. & the students replied together \\
\hline Mang Apin nanggung carangka & $\begin{array}{l}\text { Mang Apin carried up the big bamboo } \\
\text { basket }\end{array}$ \\
\hline
\end{tabular}


Then, the synonymy is used when a word in SL has no any equivalence in TL. However, there is alternative for the word in TL that has similar meaning with the translated word. For instance, the word waas in the clause "Bakal waas geura, Mod" is translated as "It must be very mesmerizing, Mod" to still maintain the thrilling feeling from the word waas.

The explicitation procedure is applied by explicitely tell the meaning to complete the information from the SL that might not be known by the reader in TL. For example, the clause "geus kadéngé sora kohkol sapuluh kali." was translated into kohkol had been struck ten times, the sign that it had been already 10.00 P.M.",

\section{Cultural Words}

Understanding cultural aspects of source language and target language is essential in conducting translation project in order to produce a translation which sounds natural in the target language. The cultures influence a lot in the result of the translation. The book $\mathrm{Nu}$ Ngageugeuh Legok Kiara contains a lot of Sundanese culture. To translate it into English is quite challenging since the culture should be transfered too. In doing the translation, there were found some words that are related to Sundanese culture and those words cannot be transfered into English.

In translating the cultural words, the original words are still mentioned as in the original text. It is intended to achieve the purpose of the project i.e. to introduce the Sundanese culture to the reader. However, to make it understandable, some translation procedures are used. Here are the examples of cultural words found.

Table 10 Examples of Cultural Words

\begin{tabular}{|l|l|}
\hline $\begin{array}{l}\text {... ceuk Mang Apin bari kop kana } \\
\text { bubuy sampeu. }\end{array}$ & $\begin{array}{l}\text {...said Mang Apin as he ate bubuy sampeu (cassava } \\
\text { that has been cooked by putting it on hot ashes) }\end{array}$ \\
\hline Hawu & $\begin{array}{l}\text { hawu (traditional stove with open fire, made from } \\
\text { heap of bricks). }\end{array}$ \\
\hline $\begin{array}{l}\text { Emod ngajinjing kantong kérésék } \\
\text { dieusi timbel. }\end{array}$ & $\begin{array}{l}\text { Emod brought a plastic bag containing timbel (rice } \\
\text { that is covered by banana leaves) }\end{array}$ \\
\hline
\end{tabular}

Other cultural words can be found below. 
Table 11: List of Cultural Words

\begin{tabular}{|c|c|c|}
\hline & Cultural Words & Translation \\
\hline 3 & Timbel & timbel (rice that is covered by banana leaves) \\
\hline 4 & Dudukuy & $\begin{array}{l}\text { dudukuy (Sundanese traditional hat which has wide shade } \\
\text { around the hat) }\end{array}$ \\
\hline 5 & Sambel & $\begin{array}{l}\text { Sambel : crushed chillis with other optional spices such as } \\
\text { shallot, garlic, shrimp paste, etc. }\end{array}$ \\
\hline 6 & Ngaronda, ronda & $\begin{array}{l}\text { the activity of securing the village in the night by the people } \\
\text { in an area to check and inform if there are urgent situations } \\
\text { such as robbery, fire, or earthquake. }\end{array}$ \\
\hline 7 & Sééng & $\begin{array}{l}\text { sééng (traditional cooking equipment made of steel, used for } \\
\text { steaming, boiling water, etc.) }\end{array}$ \\
\hline 8 & Pupuh Kinanti & $\begin{array}{l}\text { Pupuh Kinanti: A kind of traditional folk song named Pupuh } \\
\text { from Sundanese culture. Different pupuh has different rule of } \\
\text { sylable and rhyme. }\end{array}$ \\
\hline 9 & Panyawah & $\begin{array}{l}\text { People who help in the ricefields by ploughing the soil, } \\
\text { watering, and helping with the livestocks. }\end{array}$ \\
\hline 10 & Ashar & $\begin{array}{l}\text { Time for afternoon pray for Moslem, the time can be from } 3 \\
\text { to } 4 \text { P.M. }\end{array}$ \\
\hline 11 & Tampian & Public toilet or bathroom that is used by people in an area \\
\hline 12 & Pancuran & bamboo stem that flows water so that it functions as pipe \\
\hline 13 & Kohkol & $\begin{array}{l}\text { An instrument made from wood, usually found in pos ronda, } \\
\text { used for informing people by beating it with a wooden stick }\end{array}$ \\
\hline 14 & Napikeun, tapi & An activity to clean the rice from its skin by using nyiru \\
\hline 15 & Golodog & Stairs made of wood to get into the traditional house \\
\hline 16 & Keris & $\begin{array}{l}\text { Traditional dagger with double-edged blade and has wavy } \\
\text { shape, some believe that it has supranatural power or is } \\
\text { protected by supernatural creatures. }\end{array}$ \\
\hline 17 & Parako & $\begin{array}{l}\text { Place above hawu to put woods or dry branches for the fuel } \\
\text { of the stove }\end{array}$ \\
\hline 18 & Sayur asem & $\begin{array}{l}\text { Sundanese traditional food, a kind of soup that consists of } \\
\text { some kinds of vegetables such as kidney beans, melinjo nut, } \\
\text { melinjo leaves }\end{array}$ \\
\hline 19 & Seupaheun & $\begin{array}{l}\text { An activity of securing the village in the night by the people } \\
\text { in an area to check and inform if there are urgent situations } \\
\text { such as robbery, fire, or earthquake. }\end{array}$ \\
\hline 20 & Bedog & Sundanese traditional sword/machete \\
\hline 21 & Magrib & $\begin{array}{l}\text { It is when the sun sets, one of the time for Moslem do } \\
\text { praying in a day. }\end{array}$ \\
\hline
\end{tabular}




\section{Conclusions and Recommendations}

In conducting this translation project, there are problems that we faced. The first problem is the difficulty to find the equivalence of some words or phrases that are commonly used in the target language. This problem was found especially when translating the cultural words. To overcome this problem, looking up the dictionaries and browsing on the internet were very helpful. In addition, I also consulted with people who are native speakers of both languages to know the meaning of the difficult words.

The next problem is to make sure that my translation is appropriate to have it proofread by other people who are good in both languages (English and Sundanese) is difficult. However, we made myself brave enough to do this work as we would like to promote our Sundanese language and literature through translating this novelette.

For those who are going to conduct a similar project, there are some recommendations that may be useful to make a better translation result. First, we have to master and understand both source language and target language; it can help to produce an accurate, readable, and natural translation. Second, choose a literary work rich with cultural events or information. This will make our work interesting and the same time can be challenging. Choose professional people who are willing to help in doing the project is a good idea, but to rely on ourselves is good as long as we are both confident with or both tarket and source language.

Translating a Sundanese novelette into English is challenging. To do it, we have to have a wider knowledge about Sundanese culture. We hope my work can inspire others to do similar work. What we have translated is a novelette or prose. It would be interesting to translate other types of literary works such as poems and short story. There are a great number of such literary works and people in foreign countries would be eager to know other Sundanese literary works.

\section{References}

- $\quad$ Bassnett, S. (2002). Translation studies. London and New York: Routledge.

- Delisle, J. (1999). Translation Terminology. Amsterdam and Philadelphia: John Benjamins 
- Djajadilaga, T. (2014). Nyi Sarikingkin. Bandung: Kiblat Buku Utama.

- Durdureanu, I. I. (2011). Translation of cultural terms: Possible or impossible?. Journal of Linguistic and Intercultural Education, 4, 51-63.

- $\quad$ Hirata, A. (2009). Rainbow troops (A. Kilbane, Trans.). Yogyakarta: Bentang Pustaka.

- $\quad$ Larson, M. L. 1984. Meaning Based Translation, A Guide to Crosslanguage Equivalence. Lanham: University Press of America, Inc.

- Mustakim. (2013). Bahasa Sunda akan lebih cepat punah dibandingkan bahasa Bali. Retrieved from http://www.pikiranrakyat.com/seni-budaya/2013/02/21/224150/bahasa-sunda-akan-lebihcepat-punah-dibandingkan-bahasa-bali

- Newmark, P. (1988). A textbook of translation. Hertfordshire: Prentice Hall.

- $\quad$ Nida, E. A. (1984). On translation. Beijing: Translation Publishing Corp.

- $\quad$ Ordudari, M. (2007). Translation procedures, strategies, and methods. Translation Journal. Retrieved from http://translationjournal.net/journal/41culture.htm

- $\quad$ Restanto, S. A. H (2011). Legenda Ajisaka: Asal Mula Aksara Jawa - Legend of Ajisaka: Chronicle of Hanacaraka. Retrieved from http://www.slideshare.net/samsurvive/buku-cerita-bergambar-bilinguallegenda-ajisaka-untuk-anakanak?from_action=save

- Romli, U. (2010). Oray bedul macok Mang Konod. Bandung: Penerbit Cupumanik.

- Rosidi, A. (2012). Si Pucuk Kalumpang.Bandung: Kiblat Buku Utama.

- $\quad$ Sutisna, D. (2001). Nu ngageugeuh Legok Kiara. Bandung: Kiblat Buku Utama.

- $\quad$ Vinay, J-P. \& Darbelnet, J.C. (1965). Stylistique comparie du francais et de Vanglais, Paris: Didier. 